\title{
Between Title IX and the Criminal Law: Bringing Tort Law to the Campus Sexual Assault Debate
}

\author{
Sarah L. Swan* \\ INTRODUCTION
}

In a recent televised debate, four law professors partnered up to argue for, or against, the following proposition: "Courts, not campuses, should decide sexual assault cases." 1 Their staged debate reflected the heated discussion occurring in society more broadly over the most appropriate forum and method for addressing campus sexual assault. As campus sexual assault has finally ascended to the status of a national concern, attracting the attention of even the White House, two main camps have emerged: those who believe campus sexual assault is a crime, and thus best dealt with in the criminal courts, using criminal law tools; and those who believe campus sexual assault is a civil rights violation, and thus best dealt with through university disciplinary proceedings, using Title IX. ${ }^{2}$

The criminal law camp argues that because campus sexual assault is a crime, it falls under the domain of the police and the criminal courts. Further, they argue that universities lack the institutional competency to address sexual assault, since sexual assault is nothing like plagiarism or the

* Associate-in-Law, Columbia Law School. Many thanks to Marie-Amelie George, Ryan Liss, Shari Motro, Allison Tait, and the participants of the Columbia Law School Associates and Fellows Workshop for their comments and conversations.

1. Courts, not Campuses, Should Decide Sexual Assault Cases, InTElligence ${ }^{2}$ Debates (Sept. 16, 2015), http://intelligencesquaredus.org/debates/past-debates/item/1402-courts-notcampuses-should-decide-sexual-assault-cases.

2. Compare Nancy Gertner, Sex, Lies and Justice: Can We Reconcile the Belated Attention to Rape on Campus with Due Process?, THE AMERICAN PROSPECT, (Winter 2015), http://www.prospect.org/article/sex-lies-and-justice, and Wendy Kaminer, Victimizing the Accused? Obama's Campus Sexual Assault Guidelines Raise Concerns, 90.9 WBUR COGNOSCENTI BLOG (May 5, 2014), http://cognoscenti.wbur.org/2014/05/05/due-process-and-sexual-assault-wendykaminer, and Elizabeth Bartholet et al., Rethink Harvard's Sexual Harassment Policy, THE Boston GLOBE (Oct. 15, 2014), https://www.bostonglobe.com/opinion/2014/10/14/rethink-harvard-sexualharassment-policy/HFDDiZN7nU2UwuUuWMnqbM/story.html, with Alexandra Brodsky, Fair Process, Not Criminal Process, is the Right Way to Address Campus Sexual Assault, THE AMERICAN PROSPECT (Jan. 21, 2015), http://prospect.org/article/fair-process-not-criminal-process-right-wayaddress-campus-sexual-assault, and Amy Chmielewski, Comment, Defending the Preponderance of the Evidence Standard in College Adjudications of Sexual Assault, 2013 B.Y.U. EDUC. \& L.J. 143, 148 (2013). 
other kinds of wrongs which universities normally deal with under honor codes and disciplinary procedures. ${ }^{3}$ They warn of many anecdotal instances of what appear to be universities egregiously mishandling claims. ${ }^{4}$ In their view, universities generally function like kangaroo courts trampling the rights of students accused of sexual misconduct. ${ }^{5}$

The Title IX camp, on the other hand, argues that because campus sexual assault is a civil rights violation, it falls under the domain of the university. ${ }^{6}$ They point out that just as Title VII of the Civil Rights Act of 1964 guaranteed a right to equal opportunity in employment, "Title IX guarantees broad rights to an equal education." "7 As part of its equal education guarantee, Title IX prohibits sex discrimination and other forms of gender or sexually-based violence, and obligates universities receiving federal funds to maintain a non-discriminatory environment. ${ }^{8}$ Title IX advocates therefore argue that this civil rights system has little to do with the criminal law, and that the disciplinary systems within universities are best able to offer an adjudicative system that promotes these goals. ${ }^{9}$ They resist the attempted "criminalization" of Title IX, and argue that the criminal law offers neither an appropriate forum, nor the appropriate tools, with which to address campus sexual assault. ${ }^{10}$

This Symposium essay argues that there is an important piece missing from the polarized criminal law versus Title IX conversation. The narrow framing of Title IX versus the criminal law ignores a third possible

3. See, e.g., The Times Editorial Board, Can Colleges Handle Sexual Assault Cases Fairly?, LOS ANGELES Times (July 17, 2015), http://www.latimes.com/opinion/editorials/la-ed-sexualassault-uc-san-diego-case-20150717-story.html.

4. A disciplinary proceeding at Occidental College has been particularly criticized. See Peter Jacobs, How 'Consensual' Sex Got a Freshman Kicked Out of College And Started a Huge Debate, BUSINESS INSIDER (Sept. 15, 2014, 1:45 PM), http://www.businessinsider.com/occidental-sexualassault-2014-9.

5. See, e.g., Greg Piper, California Ruling Could End Kangaroo-Court Investigations of Campus Rape, Law Professor Says, THE COllege FIX (Oct. 12, 2015), www.thecollegefix.com/post/24610/.

6. See, e.g., Nancy Chi Cantalupo, For the Title IX Civil Rights Movement: Congratulations and Cautions, 125 YAle L. J. Forum 281, 285-86 (2016).

7. Id. at 282. See also Chmielewski, supra note 2, at 153-54 ("Title IX is not the only legal context in which rape and sexual assault have been understood as civil rights violations .... Most notably, the Violence Against Women Act of 1994 ("VAWA") took this approach in creating a civil rights cause of action for 'crimes of violence motivated by gender."').

8. Title IX declares that "No person in the United States shall, on the basis of sex, be excluded from participation in, be denied the benefits of, or be subjected to discrimination under any education program or activity receiving Federal financial assistance.” 20 U.S.C. §§ 1681-1688 (2012).

9. Cantalupo, supra note 6, at 284.

10. Id. at 284-85. 
characterization of campus sexual assault: it is also a tort. ${ }^{11}$ In addition to being a crime, and a civil rights violation, campus sexual assault is also a private, tortious wrong, and thus potentially subject to adjudication in civil court, using the usual rules of civil procedure. Moreover, tort law offers more than just a third mode of adjudication potentially available to those who experience campus sexual assault; acknowledging that campus sexual assault is a tort, capable of redress in the private law system, also offers important conceptual insights for the campus sexual assault debate. Specifically, the reconceptualization of campus sexual assault as a tort can help resolve three contested issues where the Title IX approach and the criminal law approach dramatically clash.

Part I of this Symposium piece explores why tort law has been left out of the campus sexual assault debate. Much of the explanation lies in history. For hundreds of years, legal redress for sexual assault has shifted back and forth, oscillating between rape as a public, criminal wrong, and rape as a private, civil wrong. Different eras have had different emphases. However, for the last century, sexual assault has been understood as predominantly criminal. In fact, this framing has become so powerful that it is often difficult to think of sexual assault as anything other than a crime. Part I attempts to break this conceptual stranglehold by recounting how tort law is also an important, though often ignored, means of redressing sexual assault. As an additional non-criminal framing for the wrong of sexual assault, tort law thus supports the Title IX position that other non-criminal characterizations of and approaches to campus sexual assault can also be valid.

Part II argues that incorporating tort law into the campus sexual assault conversation generates important insights that can assist in resolving three contentious issues in the campus sexual assault debate. ${ }^{12}$ The first issue concerns the extent to which law enforcement should have a hegemony on sexual violence adjudication. ${ }^{13}$ Tort law suggests that the current wave of legislation proposing that schools must "refer all reports of sexual violence... to law enforcement" is misguided, ${ }^{14}$ and reminds us of the importance of having complainant-driven processes in the sexual assault

11. Some commentators have noted connections between tort and campus sexual assault, but do not offer a sustained analysis of this point. See, e.g., Chmielewski, supra note 2, at 150; Sherry F. Colb, "Yes Means Yes" and Preponderance of the Evidence, DORF ON LAW BlOG (Oct. 29, 2014, 8:30 AM), www.dorfonlaw.org/2014/10/yes-means-yes-and-preponderance-of.html.

12. See Cantalupo, supra note 6, at 285 .

13. Id.

14. Id. 
context. Second, tort law may set the appropriate scope of procedural protections for campus sexual assault adjudications. Although criminal law advocates have made a "concerted effort to import criminal due process requirements into campus disciplinary and grievance proceedings,", civil due process requirements are arguably a better touchstone, since the consequences of being held responsible for campus sexual assault in a Title IX proceeding are very similar to the consequences of a civil finding of liability for sexual assault, and very unlike the consequences of a criminal conviction. Third, through an analysis of the consent element in tort claims for sexual assault, the newly instituted standard of affirmative consent becomes more defensible. Ultimately, bringing tort law into the campus sexual assault debate opens up the vast and fertile ground between the two poles of criminal and Title IX, thereby helping to resolve existing points of contention and to clear the path towards better institutional design and a more effective solution to this social problem.

\section{THE EXCLUSION OF TORT LAW}

The debate between the criminal law approach and the Title IX approach often plays out in the media. Voices calling for the criminal law approach to campus sexual assault are heard in op-ed articles like Why Colleges Should Report Sex Crimes, Pronto, to Police and Prosecutors; ${ }^{16}$ Colleges are Not Equipped to Investigate Sexual Assault ${ }^{17}$ Law Enforcement Must Take the Lead in Campus Sexual Assault Cases,${ }^{18}$ and Time to Call the Cops: Title IX has Failed Campus Sexual Assault. ${ }^{19}$ Title IX advocates, on the other hand, try to persuade the public that colleges can effectively and justly adjudicate these claims, through articles like The Promise of Title IX: Sexual Violence and the Law; ${ }^{20}$ No, We Can't Just

\footnotetext{
15. Id.

16. Editorial Board, Why Colleges Should Report Sex Crimes, Pronto, to Police and $\begin{array}{llllll}\text { Prosecutors, } & \text { CHI. } & \text { TRIB. } & \text { (Aug. 28, 2015, 11:49 AM), }\end{array}$ http://www.chicagotribune.com/news/opinion/editorials/ct-sex-assault-campus-crime-reporting-rapepolice-edit-0830-jm-20150828-story.html.

17. Dante Ramos, Colleges Are Not Equipped to Investigate Campus Sex Assaults, Bos. GLOBE (June 3, 2015), https://www.bostonglobe.com/opinion/2015/06/02/are-colleges-equippedinvestigate-campus-sexual-assault/mFFOINP8LIr7EQ1dYQt2AN/story.html.

18. Samantha Harris, Law Enforcement Must Take the Lead in Campus Sexual Assault Cases, N.Y. TimeS (Aug. 13, 2014, 12:32 PM), http://www.nytimes.com/roomfordebate/2014/08/12/doingenough-to-prevent-rape-on-campus/law-enforcement-must-take-the-lead-in-campus-sexual-assaultcases.

19. Robert Shibley, Time to Call the Cops: Title IX Has Failed Campus Sexual Assault, TimE (Dec. 1, 2014), http://time.com/3612667/campus-sexual-assault-uva-rape-title-ix/.

20. Alexandra Brodsky \& Elizabeth Deutsch, The Promise of Title IX: Sexual Violence and the
} 
Leave College Sexual Assault to the Police $;^{21}$ and Campuses are the Best Place for Accountability. ${ }^{22}$

Both sides argue that the other lacks the institutional competency to adequately address campus sexual assault. Criminal law advocates point to numerous examples of apparently botched Title IX investigations, and emphasize a perceived lack of expertise on the part of the college community members involved with sexual assault adjudication. ${ }^{23}$ For their part, Title IX advocates also use institutional competency arguments, and point to the fact that the criminal law has a woeful track record of addressing sexual assault. ${ }^{24}$ Even rape reforms like rape shield laws have done little to actually change rape reporting or conviction rates. A growing scholarly consensus supports the position that the criminal law may simply be structurally unable to adequately address sexual assault, ${ }^{25}$ and Title IX advocates therefore argue that Title IX's civil rights approach has a much greater chance of successfully addressing this social problem.

Neither side uses tort law as a basis for argumentation. Given that the "tortification" of federal civil rights law is a fairly well recognized phenomenon, ${ }^{26}$ it is perhaps surprising that tort law has not been a larger part of the campus sexual assault conversation. There is a deep "connection between civil rights and civil wrongs," and courts frequently explicitly rely on tort law when interpreting civil rights and anti-discrimination law, and have asserted not only that they may do so, but that they should do so. ${ }^{27}$

Law, DisSENT MAG. (Fall 2015), https://www.dissentmagazine.org/article/title-ix-activism-sexualviolence-law.

21. Alexandra Brodsky \& Elizabeth Deutsch, No, We Can't Just Leave College Sexual Assault to the Police, Politico MAG. (Dec. 3, 2014), http://www.politico.com/magazine/story/2014/12/uvasexual-assault-campus-113294.

22. Holly Rider-Milkovich, Campuses are the Best Place for Accountability, N.Y. TIMES (Aug. 12, 2014), http://www.nytimes.com/roomfordebate/2014/08/12/doing-enough-to-prevent-rape-oncampus/campuses-are-the-best-places-for-sexual-assault-accountability.

23. Christina Hoff Sommers, In Making Campuses Safe for Women, a Travesty of Justice for Men, CHRON. OF HIGHER EDUC. (June 5, 2011), http://chronicle.com/article/In-Making-CampusesSafe-for/127766/. Many also argue that campus sexual assault investigations and adjudications may have a racialized component. See Jeannie Suk, Shutting Down Conversations About Rape at Harvard Law, NEw YORKER (Dec. 11, 2015) www.newyorker.com/news/news-desk/argumentsexual-assault-race-harvard-law-school.

24. Sarah L. Swan, Triangulating Rape, 37 N.Y.U. Rev. L. \& Soc. Change 403, 407 (2013).

25. See, e.g., Deborah Tuerkheimer, Rape On and Off Campus, 65 EMORY L.J. 1, 2 (2015); Aya Gruber, Rape, Feminism, and the War on Crime, 84 WASH. L. REv. 581, 585 (2009); Samuel W. Buell, Culpability and Modern Crime, 103 GEO. L.J. 547, 551 (2015).

26. See Sandra F. Sperino, Let's Pretend Discrimination is a Tort, 75 Oніо ST. L.J. 1107, 1109 (2014); Martha Chamallas \& Sandra F. Sperino, Torts and Civil Rights Law: Migration and Conflict: Symposium Introduction, 75 OHIO ST. L.J. 1021, 1021 (2014).

27. Chamallas \& Sperino, supra note 26, at 1021. 
Indeed, the U.S. Supreme Court has held that in creating the "federal tort" contained in Title VII, Congress "adopt[ed] the background of general tort law." ${ }^{28}$ Further, the Court has declared that tort rules are the "default rules" of antidiscrimination law. ${ }^{29}$

There has also been a tortification of criminal law. Although tort and crime are distinct legal regimes, recently "the tort/crime line" has blurred. ${ }^{30}$ So-called crimtorts (torts that remedy public harms and arguably serve a public purpose) are one example of this blurring, ${ }^{31}$ as is the infiltration of tort concepts into areas like regulatory and traffic crimes. ${ }^{32}$ Indeed, the criminal law regarding sexual assault may soon undergo its own tortification, if the currently proposed American Legal Institution draft on sexual assault is accepted. It imports a "tort negligence standard for criminal liability" for sexual assault in some circumstances. ${ }^{33}$

Despite its increasing presence in criminal and antidiscrimination law, tort has been largely absent from the campus sexual assault conversation. There is a simple, two-part explanation for this. First, few students have actually used tort law as a means of addressing campus sexual assault. ${ }^{34}$ Although it is an available avenue of relief, individuals who experience campus sexual assault do not often access the civil courts and bring tort claims.

The second part of the explanation relates to why this is so: for most of recent modern history, the idea that rape is a crime and thus best dealt with within the confines of the criminal law has been dominant. Rape is most

28. Id. (quoting Staub v. Proctor Hosp., 562 U.S. 411, 417 (2011)).

29. Id. (quoting Univ. of Tex. Sw. Med. Ctr. v. Nassar, 133 S. Ct. 2517, 2525 (2013)). In general, tort law has been seen as weakening civil rights law. See Anthony Sebok, What Happens if We Call Discrimination a Tort?, JoTwELL (Dec. 17, 2015), http://torts.jotwell.com/what-happens-ifwe-call-discrimination-a-tort/.

30. Noah M. Kazis, Comment, Tort Concepts in Traffic Crimes, 125 YALE L. J. 1131, 1134 (2016).

31. See Thomas H. Koenig, Crimtorts: A Cure for Hardening of the Categories, 17 WIDENER L. J. 733, 737-38 (2008).

32. Kazis, supra note 30, at 1133-34.

33. Greg Piper, Attempt to Quietly Redefine Sexual Assault in U.S. Law Draws Backlash from Lawyers, THECOLLEGEFIX.COM (Jan. 26, 2016) www.thecollegefix.com/post/25983 (quoting Professor Kevin Cole). Aya Gruber argues that tort law has already seeped into criminal rape trials. She describes how contributory negligence and assumption of risk defenses have been imported into criminal law, to the detriment of rape victims. Aya Gruber, Pink Elephants in the Rape Trial: The Problem of Tort-Type Defenses in the Criminal Law of Rape, 4 WM. \& MARY J. WOMEN \& L. 203, 211 (1997).

34. Ellen Bublick, Tort Suits Filed by Rape and Sexual Assault Victims in Civil Courts: Lessons for Courts, Classrooms and Constituencies, 59 S.M.U. L. REV. 55, 75-84 (2006) (noting that tort cases that are brought often focus on the school's role in the assault). 
often thought of as a quintessential criminal wrong, as a violent crime that deviant, pathological strangers-in-bushes perpetuate, and thus one that is rightly punished through the full punitive weight of the state. ${ }^{35}$

However, it was not always thus. Historically, rape has "often blurred the line between a public and private offense, and different periods and regimes emphasized each of these aspects." law, for instance, emphasized rape as a private wrong. ${ }^{37}$ Conversely, in the fourth and fifth century, rape was predominantly addressed as a public wrong. ${ }^{38}$ These switches in emphasis reveal that, essentially, " $[t]$ he conception of rape as being fundamentally a public wrong, or fundamentally a private wrong" is more of a "political position" than "an innate quality" of the harm. ${ }^{39}$

Because rape originally protected a patriarchal interest, and was initially understood as a "violation of an authoritative male's property right [in a woman]" rather than a "personal harm to the woman herself," for centuries only fathers, husbands, and masters could bring civil actions for rape. ${ }^{40}$ Finally, in the mid-nineteenth century, women became able to assert their own sexual battery claims, but only through the cause of action of seduction, a wrong which was also both private and public, both a tort and a crime. ${ }^{41}$ It was not until the early twentieth century that some state laws began recognizing civil liability for rape in a more direct way, but they did so in the face of an already strongly-entrenched notion that rape was a public wrong. Several states had criminal law doctrines "“designed to discourage private recovery for what many considered a public wrong,' and in many jurisdictions there was a 'general cultural reluctance to transform so serious a public wrong into a claim for monetary damages.",42

Because of these cultural views, "[t]he explicit recognition of rape as a basis for civil liability did not immediately give rise to much civil litigation in this area." to the occurrences of sexual assault, it is still quite small. ${ }^{44}$ Nevertheless, civil claims for sexual assault is a growing area of litigation, and an

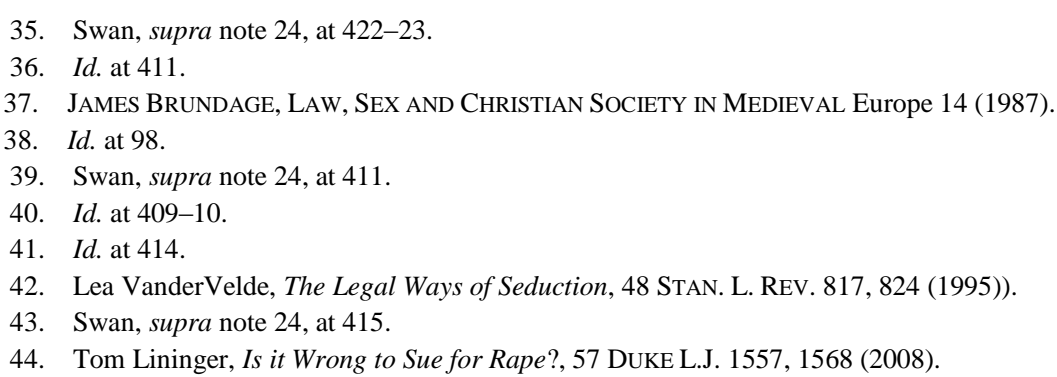


increasing number of litigants are using the civil courts as either an alternative or a complement to the criminal process. ${ }^{45}$

On college campuses, though, many complainants who want to access a formalized system of redress turn to their school's Title IX procedure, rather than to the civil courts. ${ }^{46}$ In its ideal form, Title IX offers an easy-to-access and easy-to-navigate in-house process that can, through a variety of mechanisms, help minimize the impact of sexual violence on one's education. ${ }^{47}$ In addition to Title IX, some students also at least consider the possibility of a criminal process, but many forego it because it is widely understood to be hostile to sexual assault complainants. A civil claim, on the other hand, is rarely even considered as an option, or, if it is brought to mind, is thought to require an attorney to access and navigate. ${ }^{48}$

Were students to more readily access the tort system, they would find that, while by no means perfect, it can be a viable and helpful form of redress for many complainants. ${ }^{49}$ The dominant mode of rape redress, however, remains the criminal court, and it is the criminal court that looms largest in the public imagination as the forum in which rape adjudication occurs. "[T] he vast majority of the law's involvement with sexual assault and rape takes place within the context of the criminal law system[,]" not the civil one, and the discussion surrounding campus sexual assault has also mirrored the dominance of the criminal law as a form of redress. ${ }^{50}$ The slow historical development of sexual assault as a civil wrong, and the hegemonic dominance of the criminal law as the primary mode of its redress, has

45. Swan, supra note 24 , at 424 .

46. To be clear, the categories of victim and perpetrator are gendered: in one study of claims made to an educational insurer in a two year period between 2011 and 2013, ninety-nine percent of the perpetrators of sexual assault were male, and ninety-four percent of the victims were women. UNITED EDUCATORS INSURANCE, CONFRONTING CAMPUS SEXUAL AsSAUlt: AN EXAMINATION OF Higher EDUCATION CLAIMS 3 (2015), https://www.bgsu.edu/content/dam/BGSU/humanresources/documents/training/lawroom/Sexual_assault_claim_study.pdf.

47. Cantalupo, supra note 6 , at 284 .

48. Examples of civil cases involving campus sexual assault include Weldon v. Rivera, 301 A.D.2d 934 (N.Y. App. Div. 2003) (female student raped in dorm room sued rapist and other male who watched the assault) and Nero v. Kan. State Univ., 861 P.2d 768 (Kan. 1993) (female student sexually assaulted by another student in her residence hall brought an action alleging negligence against the university and a separate action against the perpetrator).

49. Problems include access to justice issues, comparative fault rules, and the persistence of rape myths. See, e.g., Ellen M. Bublick, Citizen No-Duty Rules: Rape Victims and Comparative Fault, 99 ColuM. L. REV. 1413, 1427-41 (1999); Bublick, supra note 34, at 75-84; Swan, supra note 24, at 443-53. A prepetrator's physical presence may also be difficult for a complainant. See Tyler Kingdale, College Rape Case Highlights Emotional Toll for Victims Who Sue, HUFFINGTON Post (Aug. 31, 2015, 1:12 PM), http://www.huffingtonpost.com/entry/virginia-wesleyan-rapelawsuit_us_55ddf19be4b08cd3359e36c7.

50. Swan, supra note 24 , at 416. 
eclipsed the role of sexual assault as a tort, and campus sexual assault as a civil wrong has not yet been incorporated into the campus sexual assault debate in any meaningful way.

Title IX suffers from a similar new-kid-on-the-block syndrome, and has had difficulty establishing itself as a legitimate avenue of redress. However, when conceptually paired with tort law, these two non-criminal alternatives may help legitimate each other. Together, they reinforce the idea that there are multiple ways to approach and frame wrongs, even wrongs typically thought of as criminal.

\section{CAMPus SEXUAL Assault AS A TORTIOUS WrONG}

Once we start thinking of campus sexual assault as a wrong that is not only criminal, and not only a civil rights violation, but also a tort, three insights emerge that shed light on the most contentious areas of the Title IX versus criminal law debate. First, the tort law conceptualization helps explain why calls to refer all campus sexual assault claims to criminal law enforcement are misguided. Second, tort law sets a useful standard for the procedural protections that should apply when adjudicating claims of sexual assault, both through the procedural protections normally applicable to tort claims, and through the tort cases in which students have challenged poor procedure. Third, analyzing the consent element in a battery action (the most popular tort cause of action for sexual assault claims) helps explain why affirmative consent is an appropriate standard.

\section{A. Forwarding Claims to Criminal Law Enforcement}

By leaving tort law out of the debate, the criminal law versus Title IX debate suggests that there are only two possible ways to address campus sexual assault: the criminal law, or Title IX. As a first-best option, criminal law advocates argue that because sexual assault is a crime, campus sexual assault should remain the province of criminal authorities, and universities should simply refer cases directly to law enforcement. To that end, many legislators are currently proposing bills that would require universities to forward all claims of campus sexual assault to criminal law enforcement. ${ }^{51}$ Such legislation would essentially transform a school-based complaint into a criminal complaint, thereby “turning a victim's report to school authorities

51. Cantalupo, supra note 6, at 291. 
into an indirect report to law enforcement." ${ }^{, 52}$

Tort law supports the Title IX advocates' view that such legislation is misguided, and offers an extensive literature on the importance of complainant-driven processes. ${ }^{53}$ Through enabling a person who has been harmed to either bring a claim or not, at his or her discretion, tort law is understood as empowering victims. ${ }^{54}$ Pursuing a legal action, when one chooses to do so, asserts one's inherent dignity. ${ }^{55}$ Dignity is (at least partly) a status-concept: "it has to do with the standing (perhaps the formal legal standing or perhaps, more informally, the moral presence) that a person has in a society and in her dealings with others." process tells society that the complainant has the full "status of a person" and can "demand that her agency and her presence among us as human beings be taken seriously and accommodated in the lives of others."

Conversely, forcing an unwanted legal process onto a person is deeply problematic. In ignoring a harmed women's desire to engage or not engage a legal process, the legislation proposing mandatory criminal reporting repeats a problem of the criminal law itself: it does not honor the wishes of the person actually harmed. ${ }^{58}$ In criminal law, a victim's "consent or willingness to engage the [legal] process 'is neither necessary nor sufficient for a prosecution to be brought." "59 A victim's willingness to engage in the criminal process is not sufficient to compel prosecution; even when victims desperately want claims pursued, prosecutors frequently choose to nevertheless abandon charges. And a victim who adopts the contrary position, and prefers not to invoke the criminal process, may find that her consent or willingness to pursue a criminal complaint is unnecessary; her unwillingness is not enough to deter prosecution. ${ }^{60}$ The criminal process may proceed without her agreement, as the Sixth Circuit of the United States Court of Appeals acknowledged when it noted that "a rape victim's role in a

\footnotetext{
52. Id.

53. See, e.g., Ronen Perry, Empowerment and Tort Law, 76 TENN. L. REV. 959, 975-78 (2009).

54. JOHN C.P. GOLDBERG \& BENJAMIN ZiPURSKY, THE OXFORD INTRODUCTIONS TO U.S. LAW: TORTS 6 (2010).

55. Swan, supra note 24 , at 426.

56. Jeremy Waldron, How Law Protects Dignity 2 (N.Y.U. Sch. of Law Pub. Law \& Legal Theory Research Paper Series, Working Paper No. 11-83, 2011), http://ssrn.com/abstract=1973341.

57. Id. at 3.

58. Swan, supra note 24 , at 416-17.

59. Id. at 416 (quoting Kenneth W. Simons, The Crime/Tort Distinction: Legal Doctrine and Normative Perspectives, 17 WIDENER L. J. 719, 719 (2007)).

60. $I d$.
} 
criminal prosecution cannot accurately be described as "voluntary.",61

The denial of subjectivity inherent in a forced legal process is particularly problematic in the context of sexual assault. It exacerbates part of the harm of sexual assault itself. Rape and sexual assault are a denial of a victim's autonomy and subjectivity; they are "a form of objectification" and "an implicit claim of superiority by the more powerful actor." 62 They involve a "more powerful party [...] impos[ing] his or her will on the other, regardless of the other's desires and interests." $\mathrm{A} 3$ forced legal process mimics this objectification.

In addition to emphasizing the importance of a complainant-driven legal process in the sexual assault context, tort law, as an additional alternative framing for campus sexual assault, suggests that we interrogate the nature of these different frames, and examine what particular political ends they accomplish. Campus sexual assault is not inherently more of a crime than a civil rights violation, or inherently more of a crime than a tort. Rather, it is all of these things simultaneously; each simply targets a different aspect (a harm to society, to a group, or to an individual), involves a different process (that of the criminal law, university disciplinary hearings, or civil court), and achieves a different remedy (punishment, a combination of accommodation and punishment, or compensation). And by exposing the possibility of multiple characterizations, tort reminds us that the dogged insistence that campus sexual assault is a crime or a quintessential public wrong has a political consequence. Through labeling it as a specifically criminal wrong, the criminal characterization "serves as a form of political rhetoric, one whose 'social function ... is to repress aspirations for alternative political arrangements by predisposing us to regard comprehensive alternatives to the established order as absurd." 64 Insisting that all campus sexual assault must be funneled through the criminal law denies the possibilities that other approaches (like Title IX, and like tort) might create.

This form of political rhetoric functions to maintain the status quo. Heretofore, the "net result of emphasizing rape as a 'public' wrong that should be addressed within the criminal law system has been that most rapes go unreported, uninvestigated, and unredressed."

61. Id. (quoting Street v. Nat'1 Broad. Co., 645 F.2d 1227, 1234 (6th Cir. 1981)).

62. Id. at $425-26$.

63. Id. at 425 (quoting Ronen Perry, Empowerment and Tort Law, 76 TENN. L. ReV. 959, 961 (2009))

64. Id. at 431 (quoting Karl Klare, The Public-Private Distinction in Labor Law, 130 U. PA. L. REV. 1358, 1361 (1982)).

65. $I d$. 
would continue to perpetuate this state of affairs. The legislation would likely deter students from reporting at all, as they would understand that a report would engage the criminal process even if they did not want that result. $^{66}$ Rapes that were reported would likely continue to go uninvestigated, since the legislation would do nothing to remedy the chronic lack of follow-up and investigation for sexual assault complaints that has been shown to plague many police departments. ${ }^{67}$ The ultimate effect of such legislation, then, would be to allow sexual assault adjudication to continue to fail those who experience this harm.

\section{B. Procedural Protections}

Criminal law advocates argue, as a second best option, that if universities insist on adjudicating campus sexual assault, such adjudications should employ many criminal procedural protections. Whereas Title IX advocates argue that the adjudicative process should reflect "procedural equality," and advance the goals of civil rights generally, criminal law advocates argue that more criminal due process protections should be offered. ${ }^{68}$ According to this argument, such significant due process is warranted because those accused of campus sexual assault face the possibility of expulsion, which is a severe consequence that "can follow students their entire lives." $" 69$

\section{The Significance of Stigma and Expulsion}

Expulsion, however, is much more like the consequences of a civil law judgment than a criminal one. The reputational and monetary consequences of a decision in favor of a plaintiff in a tort action involving sexual assault and a decision in favor of a complainant in a campus sexual assault

66. Cantalupo, supra note 6, at 293.

67. See Swan, supra note 24, at 421 (describing how police departments have systemically mishandled rape cases).

68. Cantalupo, supra note 6, at 294.

69. Janel Davis \& Shannon McCaffrey, Wrongly Accused of Rape? Students Question Their Expulsions from Tech, MYAJC.COM (Jan. 16, 2016), http://www.myajc.com/news/news/local/wrongly-accused-of-rape-students-question-their-ex/np59z/ (quoting Republican Rep. Earl Ehrhart); see also Dwight B. Shepard, Former Amherst College Student, Accused of Rape, Sues School Over Expulsion, MASSLIVE.COM (May 30, 2015, 8:00 AM), http://www.masslive.com/news/index.ssf/2015/05/former_amherst_college_student.html. There is also an argument that if this is so, that should have a positive deterrent effect. See Jake New, Requiring a Red Flag, INSIDE HIGHER ED (July 10, 2015), https://www.insidehighered.com/news/2015/07/10/states-requiring-colleges-note-sexual-assaultresponsibility-student-transcripts. 
proceeding are alike. Regarding the reputational impact, finding a defendant liable for sexual assault and a respondent "responsible" for sexual assault have similar repercussions. Stigma and a "mark of Cain" often accompany being known as someone who has committed a sexual assault in either context. ${ }^{70}$ However, neither a civil judgment nor a finding of responsibility are necessarily likely to travel far on their own: findings of liability in either context may not be widely broadcast or easily ascertainable. For campus proceedings, only two states (New York and Virginia) currently require colleges to note findings of responsibility for a code of conduct violation on transcripts, and in total, slightly more than $10 \%$ of schools currently engage in such notations. ${ }^{71}$ Thus, in both the university and the civil context, while some stigma may attach when others know of the findings of liability and responsibility, often the information will not be widespread. Many findings of responsibility will go unnoticed, unless someone is specifically told, or unless the adjudicatory decision is easily accessed on the Internet. And many schools that are informed that students have perpetrated sexual assault nevertheless choose to admit them, particularly when that student is a gifted athlete. $^{72}$

Economically, a student may have difficulty obtaining employment if an employer requires a copy of a transcript and the finding of responsibility is noted there, or if the student's case received media attention. ${ }^{73}$ A defendant found civilly liable for sexual assault would be in a similar situation: if his case had received media attention, that person may also have difficulty finding employment. (Additionally, if a defendant was already employed, an action for wage garnishing could alert the employer to the wrongdoing as

70. Tamara Rice Lave, Affirmative Consent and Switching the Burden of Proof, PRAWFSBLAwG (Sept. 3, 2015), http://prawfsblawg.blogs.com/prawfsblawg/2015/09/affirmativeconsent-and-switching-the-burden-of-proof.html (where blog commenters share personal knowledge of students who suffered reputational repercussions after being found responsible for campus sexual assault); see also Colb, supra note 11.

71. See Tyler Kingkade, Students Punished For Sexual Assault Should Have Transcripts Marked, Title IX Group Says, Huffington Post (Sept. 24, 2015, 4:17 PM), http://www.huffingtonpost.com/entry/sexual-assault-transcripts-

atixa_us_560420d0e4b0fde8b0d18d42; Jake New, Requiring a Red Flag, INSIDE HIGHER ED (July 10, 2015), https://www.insidehighered.com/news/2015/07/10/states-requiring-colleges-note-sexualassault-responsibility-student-transcripts. But, a commenter on Professor Tamara Lave's blog article reveals that increased broadcasting of sexual assault liability may be on the horizon. She explains that "there are bills proposed in several states to make reporting to transfer schools mandatory and also to permanently mark the student's transcript. Also, FERPA allows schools to inform other schools of a sexual assault finding, and in the current climate, most schools ask." Lave, supra note 68. See also New, supra note 67.

72. New, supra note 67.

73. Lave, supra note 68 (commenter Cynthia Garrett relaying the difficulties some of her acquaintances have had after being found liable for campus sexual assault). 
well.) A large civil judgment and expulsion are also similar in that both are economic effects: it is difficult to earn high wages without a college degree, and it is difficult to amass wealth when one's assets and income must be used to pay down a civil judgment. In both cases, one can expect a lowered net worth and resultant economic hardship.

\section{Cross-Examination and the Preponderance of the Evidence Standard}

Given the similarities between a finding of civil liability and a finding of campus misconduct, similar procedural protections should apply to both processes. ${ }^{74}$ The opportunity for discovery should be present, as well as the opportunity to present a defense. ${ }^{75}$ Legal representation should be possible. $^{76}$ Further, as the criminal law advocates suggest, campus sexual assault adjudications should include a right to cross-examine (albeit in a slightly modified form). And, as the Title IX advocates suggest, the preponderance of the evidence standard should be used.

Regarding cross-examination, "almost all" universities currently deny accused students the right to personally cross-examine the complainant. ${ }^{77}$ Indeed, the United States Department of Education Office of Civil Rights (OCR), in its 2011 Dear Colleague Letter, set out its position regarding cross-examination in campus sexual assault proceedings: "OCR strongly discourages schools from allowing the parties personally to question or cross-examine each other during the hearing. Allowing an alleged perpetrator to question an alleged victim directly may be traumatic or intimidating, thereby possibly escalating or perpetuating a hostile

74. At least to the extent that they can: Title IX does not give universities some of the powers of civil courts, like the power to subpoena. KC Johnson, College Attorneys Face the War on Due Process, MINDING THE CAMPUS (June 27, 2014), http://www.mindingthecampus.org/2014/06/college-attorneys-face-the-war-on-due-process/.

75. The Office of Civil Rights (OCR) also suggests that these procedural protections should be in place. It recommends that campus sexual assault adjudication should involve the "adequate, reliable, and impartial investigations of complaints, including the opportunity to present relative witnesses and other evidence" and "timely access to any information that will be used at the hearing." Letter from Russlynn Ali, Assistant Sec'y for Civil Rights, U.S. Dep't of Educ. to Title IX coordinators 11 (Apr. 4, 2011), http://www2.ed.gov/about/offices/list/ocr/letters/colleague201104.pdf.

76. Ideally, legal representation would not only be possible, but guaranteed. Harvard Law School, for example, will provide funds for accused students to hire attorneys if they cannot personally afford one. HLS Sexual Harassment Resources and Procedures for Students, HARVARD LAW SCHOOL (Dec. http://hls.harvard.edu/content/uploads/2015/07/HLSTitleIXProcedures150629.pdf.

77. Lave, supra note 68 (Professor Tamara Lave responding to blog commenters who share her concern that disciplinary proceedings on campus leave the accused with little chance to avoid liability, even if innocent). 
environment." 78

However, while the parties may not be permitted to directly ask questions themselves, most schools allow for the parties to cross-examine through another person, either a hearing officer or an advocate. ${ }^{79}$ This position strikes an appropriate balance of procedural protections, giving the respondent the benefits of cross-examination while at the same time ensuring the complainant is not unduly malevolently interrogated. ${ }^{80}$ It is important, though, as the California Superior Court recently affirmed in Doe v. Regents of the University of California San Diego, that the third-party tasked with asking questions actually do so. ${ }^{81}$ In Doe, "only nine of Petitioner's thirty-two questions were actually asked by the Panel Chair., $\$ 82$ This anemic approach "curtailed" the accused's right to confrontation, which is "crucial to any definition of a fair hearing."

The close parallel between civil courts and Title IX in terms of consequences for the defendant also suggests that preponderance of the evidence is a defensible standard. Some have argued that because sexual assault is a serious accusation, a standard of "clear and convincing" evidence should be used. ${ }^{84}$ But since no more stigma would come from a holding of "responsible" for sexual misconduct than would come from a holding of "liable" for sexual assault, and the consequence of expulsion is approximately as serious as being obligated to satisfy a large damages award, a preponderance of the evidence standard seems appropriate.

Indeed, although it is often ignored in the Title IX versus criminal law

78. Letter from Russlyn Ali, Assistant Sec'y for Civil Rights, U.S. Dep't of Educ., to Title IX Coordinators (Apr. 4, 2011), http://www2.ed.gov/about/offices/list/ocr/letters/colleague-201104.pdf.

79. Lave, supra note 68. (Professor Tamara Lave responding to blog commenters).

80. The Constitution requires very few protections for campus disciplinary proceedings. "The Supreme Court has found that, before a public university can impose serious permanent sanctions, the Fifth Amendment requires only that it provide notice that an offense has been alleged and that it is holding a hearing about the matter. At private institutions, the Constitution requires no procedural protections. That's not nearly enough." Brodsky, supra note 2; see also Wagner v. Fort Wayne Cmty. Schs., 255 F. Supp. 2d 915, 925 (N.D. Ind. 2003); Goss v. Lopez, 419 U.S. 565, 579 (1975); Matthews v. Eldridge, 424 U.S. 319, 333-34 (1976). Cf. Donohue v. Baker, 976 F. Supp. 136, 14546 (N.D.N.Y 1997). "The good news is that the U.S. Department of Education has recognized constitutional protections for accused students are too thin for fair and effective disciplinary systems. Through guidance to universities on how to investigate reports of sexual violence, the department's Office for Civil Rights (OCR) has not only protected survivors but also created the country's most robust regime of procedural rights for their alleged assailants. A student accused of rape, then, is provided far more protections than his classmate accused of plagiarism." Brodsky, supra note 2.

81. No. 37-2015-00010549-CU-WM-CTL, 2015 WL 4394597, at *2 (Cal. Super. Ct. July 10, 2015).

82. $\quad I d$. at $* 2$.

83. Id.

84. Cantalupo, supra note 6, at 290. 
debate, civil courts have offered thoughtful decisions explicitly addressing whether non-criminal sexual assault claims should command a preponderance of the evidence or some higher standard. The Canadian Supreme Court, for instance, held in F.H. v. McDougall that all civil cases, including those which involve conduct that may also be criminal (like sexual assault), are to be decided on the same standard: preponderance of the evidence. ${ }^{85}$ Prior to this decision, some courts reasoned that because sexual assault involves "higher moral blameworthiness" and a great deal of stigma, such claims should be subjected to heightened scrutiny in the civil courts. ${ }^{86}$ After carefully weighing the potential sanctions and the significance of the stigma, the Court found that the preponderance of the evidence standard was the correct one. Since the civil court consequences and the university consequences are so similar, the same evidentiary standard should arguably stand in both forums. ${ }^{87}$

\section{Tort Cases Challenging Poor Procedure}

Tort law also assists the debate over the appropriate procedural protection in campus sexual assault adjudications in another way: lawsuits alleging poor procedural processes on the part of schools often use tort law as a way of calibrating the appropriate scope of procedural protections. These lawsuits use negligence concepts to sort out the protections that are owed to both victims and perpetrators. ${ }^{88}$ Although perpetrator suits tend to attract more media attention, victims actually bring lawsuits more frequently,

85. F.H. v. McDougall, [2008] 3 S.C.R. 41. (Can.). Indeed, the preponderance of the evidence standard is used in "sexual harassment and violence law suits under civil rights and tort law; federal agency processing of Title VII claims of harassment and violence in the workplace; prison decisionmaking under the Prison Rape Elimination Act; and, as required by the Department of Education, university disciplinary investigations.” Brodsky, supra note 2.

86. Cheryl Pearson, The Advantages and Disadvantages of Civil Sexual Abuse Claims, THOMPSON DORFMAN SWEATMAN LLP BLOG (Jan. 27, 2014, 2:28 PM), http://www.tdslaw.com/knowledge-center/civil-claims-for-sexual-abuse/.

87. Gertner suggests that the test of an appropriate evidentiary standard may depend on what other procedural protections are in place. See Gertner, supra note 2. The OCR's position has become slightly murkier since the newly enacted Violence Against Women Act does not reference a specific standard, but rather simply indicates that schools must explicitly state in their sexual misconduct policies what evidentiary standard they will use. HOGAN LOVELLS US LLP, AMERICAN COUNCIL ON EDUCATION, New Requirements Imposed by the Violence Against Women Reauthorization Act 2 (Apr. 1, 2014), http://www.acenet.edu/news-room/Documents/VAWASummary.pdf. For sexual assault tort cases applying the preponderance standard, see T.P. v. Weiss, 990 N.E. 2d 1098 (Ohio Ct. App. 2013) ("T.P. proved by the preponderance of the evidence that on July 29, 2008, Weiss committed a sexual assault and battery on T.P.”).

88. United Educators Insurance, supra note 44, at 17-18. 
and those suits end up being more expensive than perpetrator suits. ${ }^{89}$ For example, one insurer estimated it spent $\$ 17$ million over two years "defending and resolving sexual assault claims," and 84 percent of that $\$ 17$ million (approximately $\$ 14.3$ million) was spent on victim-driven litigation. ${ }^{90}$

Negligence allegations figure prominently in these cases. ${ }^{91}$ "Nearly half (40 percent) of victims" alleged that the institution negligently investigated their claim, or negligently trained employees handling sexual

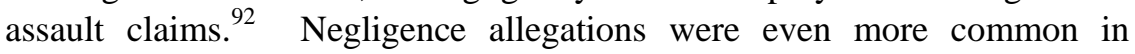
perpetrator lawsuits: 79\% alleged negligence related to the university's adjudicative process. ${ }^{93}$ As with the aforementioned example of Doe $v$. Regents of the University of California San Diego in the cross-examination context, these suits use tort to establish appropriate investigatory and adjudicative procedures. Successful suits encourage schools to adopt procedures that are fair to all parties.

\section{Affirmative Consent}

The final issue that tort law helps to resolve is that of affirmative consent. Consent has been a volatile flashpoint in the Title IX versus criminal law debate, even more so since jurisdictions like California and New York have adopted legislation imposing affirmative consent standards for colleges and universities. ${ }^{94}$ Under these new standards, "only yes means yes." 95

89. Id. at 14 .

90. Id. See also Nancy Chi Cantalupo, Violating Student Victims' Rights is Expensive, TIME (May 15, 2014), http://time.com/99697/campus-sexual-assault-nancy-chi-cantalupo/.

91. Other common causes of action include breach of contract, Title IX, and intentional infliction of emotional distress. UNITED EDUCATORS INSURANCE, supra note 44, at 17-18.

92. Id. at 16 .

93. Id. at 18 .

94. Jaclyn Friedman, Adults Hate 'Yes Means Yes' Laws. The College Students I Meet Love Them, WASHINGTON POST (Oct. https://www.washingtonpost.com/posteverything/wp/2015/10/14/adults-hate-affirmative-consentlaws-the-college-students-i-meet-love-them/.

95. Corey Rayburn Yung argues that affirmative consent standards will not significantly change case outcomes, since the legal standard for consent seems to have little actual bearing on what jurors do; cases normally turn on credibility, not legal standards; and "drunken sex cases," which form a significant portion of campus sexual assault cases, are typically decided on incapacity grounds, not on affirmative consent. Corey Rayburn Yung, California's College Rape Rule is Probably a Bad Idea (but not for the reasons the critics say), CONCURRING OPINIONS (Oct. 7, 2014), $\mathrm{http} / / /$ concurringopinions.com/archives/2014/10/californias-college-rape-rule-is-probably-a-bad-

idea-but-not-for-the-reasons-the-critics-say.html. For an example of a controversial case that turned on incapacitation, not consent, see Peter Jacobs, How 'Consensual' Sex Got a Freshman Kicked Out 
Affirmative consent is a drastic departure from the criminal concept of consent to sexual activity. Thus far, the criminal law has arguably operated on a standard that is the exact opposite of affirmative consent: a standard of "affirmative nonconsent." Under an affirmative non-consent standard, prosecutors can meet their burden of proving that there was no consent only by showing that the victim affirmatively communicated the fact of nonconsent to her assailant. ${ }^{97}$ In other words, to secure a conviction, a prosecutor "must prove actual refusal," through specific words like "no" or through physical resistance. ${ }^{98}$ Mere silence, or a void regarding consent, will not usually be the basis of a criminal conviction; the criminal law will normally understand such silence or passivity to constitute consent. ${ }^{99}$

The affirmative non-consent standard is based on "a legal presumption of female consent to sexual activity." 100 Affirmative consent, on the other hand, relies on a different default position: a presumption of non-consent. When affirmative non-consent is contrasted with the affirmative consent standard currently being promoted at colleges and universities, affirmative consent appears as such a drastic departure that critics argue it should not be entertained. But a different story appears when affirmative consent is considered in the context of the civil law. In civil law, the same presumption of non-consent that animates affirmative consent also animates much of tort law. Both operate on the principle that people have the right to be left alone. The presumption is particularly salient in the tort law of battery, an action premised on the right to be free from physical intrusions. Sexual assault claims are typically brought as battery actions. ${ }^{101}$

of College and Started a Huge Debate, BusINESS INSIDER (Sept. 15, 2014, 1:45 PM), http://www.businessinsider.com/occidental-sexual-assault-2014-9.

96. Lani Anne Remick, Comment, Read Her Lips: An Argument for a Verbal Consent Standard in Rape, 141 U. PA. L. REV. 1103, 1110 (1993).

97. Id.

98. Dana Berliner, Note, Rethinking the Reasonable Belief Defense to Rape, 100 YALE L.J. 2687, 2689 (1991) (emphasis added).

99. $I d$.

100. Remick, supra note 94 . This presumption need not be inherently offensive; "it can be viewed as merely effectuating the constitutional guarantee of a presumption of innocence and reflecting the fact that the majority of sexual interaction is consensual." Id.; see also Lawrence White, University Counsel, Georgetown University, The Legal Parameters of Consent in Cases of Alleged Sexual Battery or 'Acquaintance Assault' and the Analytically Related Issue of Institutional Policies on Consensual Sexual Relationships, Presentation at the $16^{\text {th }}$ Annual Law \& Higher Education Conference (Feb. 12-14, http://www.stetson.edu/law/conferences/highered/archive/1995/The_Legal_Parameters_of_Consent. pdf.

101. Bublick, supra note 34, at 71. In addition to battery, common causes of action for sexual assault include intentional infliction of emotional distress, assault, outrage, false imprisonment, and invasion of privacy. $I d$. 
Battery honors "the individual's unfettered choice to determine who touches his [or her] body" and "how her body will be treated by others." 102 Battery actions recognize that people are entitled to move about the world free from unwanted physical contact, and that the recognition of this right is fundamental to "core American values" of freedom, autonomy, and personal dignity. ${ }^{103}$ Battery advances "a person's legal right not to suffer unwanted, intentional, and harmful or offensive physical contacts with his or her body." 104 These rights are especially important in the context of sexual contact, since "[t]he right to make decisions about sexual partners is central to" personal autonomy, self-actualization, and freedom. ${ }^{105}$

In fact, the presumption of non-consent to physical intrusions has led some courts to find that a lack of consent is not even part of a plaintiff's battery case; instead, consent is an affirmative defense which the defendant must raise and prove. ${ }^{106}$ This is the current law in a handful of states, and is echoed abroad in countries like Canada and Australia as well. ${ }^{107}$ The draft Restatement (Third) of Torts, though, takes the position that the plaintiff in a battery case does indeed have the "burden of persuasion" to "demonstrate that he or she did not actually consent to the contact." 108 However, even with the burden still on the party advancing the claim,. establishing a lack of consent in the civil context is subject to a lower bar than in the criminal courts. The de facto affirmative non-consent standard seen in the criminal law is not present in the tort law context. Instead, there is a more balanced consent standard. The plaintiff must establish that he or she did not consent, but not to the same affirmative non-consent standard as the criminal law.

102. Deana Pollard-Sacks, Intentional Sex Torts, 77 FordHAm L. Rev. 1051, 1073, 1077 n.125 (2008) (citing DAN DOBBS, THE LAW OF TORTS 54 (2000)).

103. Id. at 1073.

104. Restatement (Third) of TORTS: Intentional TORTs to Persons $\S 101 \mathrm{cmt} . \mathrm{b}$ (Discussion Draft, Apr. 3, 2014).

105. Elizabeth Adjin-Tettey, Protecting the Dignity and Autonomy of Women: Rethinking the Place of Constructive Consent in the Tort of Sexual Battery, 39 U.B.C. L. REV. 3, 20 (2006).

106. See Nancy J. Moore, Intent and Consent in the Tort of Battery: Confusion and Controversy, 61 AM. U. L. REV. 1587, 1592 (2012).

107. Id. at 1636. In Australia, consent is an affirmative defense to battery that the defendant, not the plaintiff, must prove. In the seminal case on this issue, the judge held that to "find otherwise would be to fail to adequately recognise individual autonomy and the right to have control over one's body." Tom Tian \& Richard Sawyer, Comment, Negligent Sexual Assault: Reform of the Criminal Law and a Tort Alternative, 4 PUB. SPACE: J.L. \& SOC. JUST. 105, 116 (2009).

108. ReSTATEMENT, supra note 104 at $\$ 101 \mathrm{cmt}$. i (Discussion Draft, Apr. 3, 2014). According to the Restatement, the following elements comprise battery: (1) "the actor intends to cause a contact with the person of the other;" (2) "the actor's conduct causes such a contact;" (3) "the contact (i) is offensive or (ii) causes bodily harm to the other;" and (4) "the other does not actually consent to the contact [or to the conduct that causes the contact]." Id. at $\S 101$. 
In order to make sense of how the differing available consent standards operate in the campus sexual assault context, consider the following scenario:

Justin and Olivia are freshman. They attend the same history class, but know each other only in passing. Approximately one month into their first semester, they encounter each other at a party. Both are fairly intoxicated, but able to walk, talk, and generally function. They flirt and dance together for the rest of the evening. After party-hopping together into the wee hours of the morning, Justin invites Olivia to come to his apartment. She agrees. Once there, they begin kissing. Justin unzips Olivia's dress, and she agrees to its removal. They both get into his top bunk bed. Olivia is enjoying the kissing but is also quite tired. Justin asks Olivia if it is okay for their intimacies to advance. Olivia replies only that she is "not sure" they "know each other well enough." According to Justin's account, they then "discuss[] the matter briefly," and he "interprets[]" her remark to mean that she is concerned about his previous sexual history. He therefore offers to use a condom. She replies that he need not get up, and resumes kissing him. According to Olivia, she told him that she was unsure they knew each other well enough, and that she was not going to have sex with him because she had not had sex before and did not want to do it "on a whim." He kept stating that he had a condom somewhere else in the room. The two both agree that they subsequently had sexual relations. Justin claims it was with Olivia's "active assistance." Olivia claims that it was not, and that she made some limited attempt to push him off, but that she did not push vigorously as she was worried about falling out of the high bunk bed.

According to the affirmative non-consent standard of the criminal law, Justin would almost certainly not be convicted. The prosecution would be unable to prove beyond a reasonable doubt that there was no consent. However, according to the preponderance of the evidence standard of consent in the civil law, Justin could potentially be liable. The trier of fact could find that on these facts, it is more likely than not that there was no consent. Most university proceedings under Title IX that are not employing an affirmative consent standard would approach the issue in this way as well. Justin is similar to defendants who make a "sincere but unreasonable" mistake about consent. ${ }^{110}$ In such instances, the plaintiff prevails. ${ }^{111}$

Finally, on an affirmative consent standard, Justin would likely be found

109. This is a brief version of the real-life scenario described in White, supra note 98, at 8-10.

110. Moore, supra note 104, at 1629.

111. Id 
responsible for sexual misconduct. ${ }^{112}$ The key to affirmative consent is "only yes means yes;" ambiguous words and acts are not sufficient proof of consent. The affirmative consent standard removes the possibility of apparent consent from the legal equation. Instead of allowing ambiguity to signal consent, affirmative consent requires "explicit, unambiguous consent in fact." 113 Once the plaintiff has produced evidence of a lack of consent, to escape liability the defendant must show that there was an affirmative yes to the impugned activity. ${ }^{114}$ Here, there was no affirmative yes present, so Justin would likely be found responsible. Indeed, the trier of fact in the scenario upon which this example is based held Justin to an affirmative consent standard and found, in a written decision addressed to him, that:

An objective person in your situation would have been confused by the incongruence between the words which [Olivia] spoke and the messages her body was sending. Given that state of confusion, it was incumbent upon you to stop and talk about what [Olivia] actually wanted. Knowing of her hesitation, the burden was on you to get an explicit yes. You failed to do so and therefore engaged in intentional, nonconsensual sexually explicit touching. ...

Further:

You were persistent and overly aggressive in your attempts to verbally convince [Olivia] to have sex with you. You made assumptions about what [Olivia] wanted based on what you viewed as "shows of affection" on her part. I find that you misread these cues and engaged in sexual behavior to which [Olivia] had not given an explicit "yes."

Viewed with the criminal standard as the reference point, the leap to the affirmative consent standard used in the above decision seems extreme. However, if instead, affirmative consent is measured against the civil standard, it appears as only a slight departure, and becomes a

112. See Dan M. Kahan, Culture, Cognition, and Consent: Who Perceives What, and Why, in Acquaintance Rape Cases, 158 U. PENN. L. REV. 729, 732-35 (2010) (arguing that the legal standard of consent that jurors are asked to use has remarkably little bearing on how they judge a case; cultural norms govern instead).

113. White, supra note 98 , at 7.

114. Some scholars argue that affirmative consent standards inexcusably function to switch the burden of proof onto the defendant. Gruber, supra note 33, at 260; see also Lave, supra note 68. But see Corey Rayburn Yung, Affirmative Consent and Burden Shifting, CONCURRING OPINIONS (Sept. 3 , 2015), http://concurringopinions.com/archives/2015/09/affirmative-consent-and-burdenswitching.html (arguing that any appearance of burden shifting is due to a conflation of mens rea and actus reus requirements, such that the wrong functions like strict liability).

115. White, supra note 98 , at 10 .

116. Id. 
"comprehensible extension of consent theory in tort law.", "Nonconsensual sexual contact constitutes a serious violation of personal autonomy" and "the inherent and enduring nature of harm from sexual abuse supports the view that those who decide to engage in sexual activities with others without seeking their affirmative consent do so at their own risk."118 The affirmative consent standard exemplifies this. ${ }^{119}$

Indeed, a standard similar to affirmative consent is already present in tort law battery cases, in the context of medical negligence. ${ }^{120}$ Specifically, the kind of consent required for these claims is of a kind with affirmative consent standards. Consider Stephen J. Schulhofer's parable of surgery:

A hospitalized athlete, suffering from chronic knee problems, consults a surgeon, who recommends an operation. The athlete is not sure. If the operation is successful, he will enjoy a long, fulfilling career with his team. But there are imponderables. The operation carries a risk of a burdensome infection that can be hard to cure. The procedure may not produce the expected benefits. In any event, it is sure to be stressful in the short run. The athlete hesitates. There are clear advantages, clear disadvantages, and lots of uncertainties. What to do? Maybe he should postpone this big step for a while, see how things go without it. The surgeon is encouraging: 'Try it. You'll like it.' Still the athlete is unsure.

Now our surgeon becomes impatient. He has spent a lot of time with this case. The athlete's hesitation is becoming tiresome and annoying. So the surgeon signals an anesthesiologist to ready the drugs that will flow through an intravenous tube already in place. One last time the surgeon (a sensitive, modern male) reminds the athlete, 'You don't have to go ahead with this. If you really want me to stop, just say so.' But the athlete, his brain clouded with doubts, fears, hopes, and uncertainties, says nothing. So the surgeon starts the anesthesia and just does it. ${ }^{121}$

In this surgery scenario, we would all agree that there was no consent.

117. Id. at 7-8.

118. Adjin-Tettey, supra note 103, at 20.

119. This is not to say that the affirmative consent standard is entirely unproblematic. See Lisa Gottell, Rethinking Affirmative Consent in Canadian Sexual Assault Law: Neoliberal Sexual Subjects and Risky Women, 41 AKRON L. REV. 865, 882 (2009) (discussing how affirmative consent configures the ideal neoliberal subject and can lead to injustice for "risky" women).

120. "[C]ourts usually treat lack of informed consent to medical treatment as governed by the tort of negligence, not by the intentional tort of battery." Kenneth W. Simons, Consent and Assumption of Risk in Tort and Criminal Law, in UNRAVELling TORT AND CRIME 330, 333-34 (Matthew Dyson ed., 2014).

121. Stephen J. Schulhofer, Taking Sexual Autonomy Seriously: Rape Law and Beyond, 11 L. \& PHIL. 35, 74 (1992). 
An argument to the contrary, that there was consent because " $[t]$ he athlete was not compelled to submit. Nobody forced him ... [s]urely his silence proves that he was not unwilling. If he really objected, all he had to do was say so!" is entirely unpersuasive in this example. ${ }^{122}$ This is because we intuitively see the surgeon's actions (in proceeding even though the patient never made as a conscious choice) as violating the athlete's autonomy. ${ }^{123}$ In the surgical context, we firmly believe that affirmative resistance or nonconsent is an inappropriate standard; nor can mere silence suffice. ${ }^{124}$ In the surgical context, consent cannot mean anything less than "unambiguous, positive permission" or "an affirmative, crystallized expression of willingness." 125

Arguably, "the same conceptions of autonomy and non-consent" are equally applicable to sexual acts. ${ }^{126}$ The mental state of the patient in the surgery scenario and that described by many women in the sexual assault context are similar. Author Susan Dominus eloquently describes the experience of some women regarding consent in the sexual assault context: "in the moment, they froze, and language eluded them altogether: They said nothing. Because [words like no] are inherently confrontational, they can require a degree of strength that someone who is feeling pressured or confused or is just losing her nerve or changing her mind might not have."127 Further, like medical battery, a sexual intrusion is also a significant harm, and for such intrusions, "actual permission" or a "crystallized attitude of positive willingness" should be required. ${ }^{128}$ While there are, of course, many respects in which surgery is not like sexual activity, ${ }^{129}$ the underlying interests in battery actions in both contexts are alike. Both protect the integrity of the body from physical invasion, and both are premised on an individual's inviolate right to determine who can make physical contact with his or her body, and the parameters of such contact.

\section{CONCLUSION}

The conversation surrounding campus sexual assault has devolved into

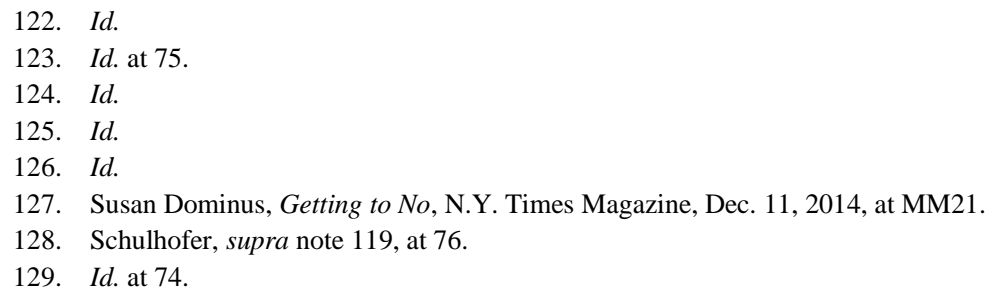


two polarized positions: one in which Title IX proceedings in the university context are the appropriate forum for adjudication of these claims, and one in which the only appropriate place of redress is the criminal court. Both sides ignore the conceptualization of campus sexual assault as a tort, and thus miss the contributions this can add to the conversation. The exclusion is understandable: it is a product of criminal law's hegemony, and the slow historical development of a civil action for sexual assault. But once the framing of campus sexual assault as a tort is brought into the campus sexual assault debate, it can assist in resolving three contentious issues. First, it suggests that the move to mandate that all campus sexual assault complaints must go through law enforcement is misguided. Second, it suggests that the appropriate procedural protections are the ones found in the civil courts. Third, tort law suggests that affirmative consent is a justifiable standard.

Tort law tells us that it is possible to fairly adjudicate sexual assault outside of the criminal justice system, and thus bolsters the Title IX argument that it is possible for universities to "hold fair hearings and comply with Title IX." 130 Moreover, tort law can help plot the path to those fair hearings. We all have a "stake in the integrity" of the campus sexual assault process: victims deserve to have their complaints efficiently and effectively addressed and their right to an equal education honored, accused students deserve to have a fair process that bears the hallmarks of procedural justice, and society as a whole deserves to have confidence that this disturbing social problem is being properly addressed. ${ }^{131}$ Bringing tort law to the campus sexual assault debate brings us one step closer to achieving these goals.

130. Jake New, Court Wins for Accused, INSIDE HigheR ED (Nov. 5, 2015) https://www.insidehighered.com/news/2015/11/05/more-students-punished-over-sexual-assault-arewinning-lawsuits-against-colleges (quoting Erin Buzuvis, Director of the Western New England University Center for Gender and Sexuality Studies).

131. Id. 